\title{
Price transmission, reserve regulation and price volatility
}

\author{
Yanwen Tan and Huasheng Zeng \\ College of Economics and Management, South China Agricultural University, \\ Guangzhou, China
}

\begin{abstract}
Purpose - The purpose of this paper is to examine whether Chinese pork reserve regulation policy fulfills its function in stabilizing market prices and simultaneously to theoretically and empirically analyze the causes leading to the failure of Chinese Government's intervention in the market, especially in the context of asymmetric pork and hog price information transmission.

Design/methodology/approach - A modified Reserve-Cobweb model based on the competitive storage model developed by Muth in 1961 is employed to examine the transmission effect of hog and pork prices under the setting of Chinese Government's pork reserve regulation policy, using the data on Chinese hog and pork prices from June 2009 to June 2015.

Findings - While the Reserve-Cobweb model provides theoretical insights, suggesting that the implementation of the government's reserve policy tool to control price volatility actually leads to increased price volatility, the empirical results indicate that the policy induces hypercorrection and impels greater price volatility, especially in the context of existence of asymmetric price information transmission. Social implications - The Chinese Government should reduce excessive pork price intervention and instead allow the market to play its role in the hog and pork markets.

Originality/value - This paper develops a modified Reserve-Cobweb model based on the price transmission effect on different links within the agricultural products supply chain, which is used to empirically validate the existence of asymmetric price information transmission between pork and hog price in China.

Keywords Asymmetric price transmission, Chinese pork price volatility, Modified Reserve-Cobweb model, Reserve regulation policy

Paper type Research paper
\end{abstract}

\section{Introduction}

Price fluctuations are a natural feature of agricultural commodity markets, as market demand meets supply under market clearing circumstances (Piot-Lepetit and M'Barek, 2011). If prices rise or fall excessively, consumers or producers will be worse off and market participants will experience price risk through market instability. After the world price for grain had experienced drastic volatility during 2007-2008, international organizations and research institutions such as the Food and Agriculture Organization, the World Bank (WB), the Organization for Economic Co-operation and Development and the International Monetary Fund (IMF) analyzed the causes behind food price spikes. Subsequent literature finds that low grain stockpiles accounted for the food price crisis of 2008 (Bobenrieth $e t$ al., 2013; IMF and UNCTAD, 2011). Moreover, storage is regarded as a main instrument in smoothing price fluctuations (Vercammen, 2012). Gouel (2012) notes that China and India that were not affected by the international market's grain price volatility in 2008 are attributed to their large stockpiles of grain accumulated.

\section{JEL Classification - Q11, Q18}

(C) Yanwen Tan and Huasheng Zeng. Published by Emerald Publishing Limited. This article is published under the Creative Commons Attribution (CC BY 4.0) licence. Anyone may reproduce, distribute, translate and create derivative works of this article (for both commercial and noncommercial purposes), subject to full attribution to the original publication and authors. The full terms of this licence may be seen at http://creativecommons.org/licences/by/4.0/legalcode

Funding source: National Natural Science Foundation of China 71373087.

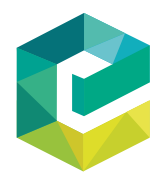

China Agricultural Economic Review Vol. 11 No. 2, 2019 pp. $355-372$ Emerald Publishing Limited 1756-137X 
CAER 11,2

Theoretically, the commodities stored influence market supply and demand by lowering purchase prices and raising sales prices and promoting market clearing (Piot-Lepetit and M'Barek, 2011). However, that just how much storage actually limits commodity price volatility has been the subject of debate. Historically, world grain storage plays a limited role in lowering food price volatility (IMF and UNCTAD, 2011); and in the long run, buffer stocks (world grain storage) are found to be ineffective in containing price volatility (Anokye and Oduro, 2013). Some scholars argue that government intervention squeezes out the effect of private storage firms in the market (Lowry et al., 1987). Moreover, there is evidence that grain price bubbles are higher under conditions of having a significant buffer stock (Bobenrieth and Wright, 2009). Nevertheless, Larson et al. indicates that the strategic reserve program is efficient while the storage costs of adopting such a policy are likely to be high when the price the government aims to achieve is high and the storage is adequate, After 2006, Chinese grain prices have stabilized without being affected by international markets' grain price volatility; while pork, vegetables and mung bean prices have exhibited volatilities. Between October 2006 and June 2007, the rise of pork prices was the main factor triggering the rise in poultry, egg and seafood prices (Cheng et al., 2008). Aiming to reduce pork price volatility, the Chinese Government has introduced a pork reserve regulation policy. While the government bought and stored pork when the pork price was very low, it released those stored pork into the market when pork retail prices were high. However, Chinese pork prices have still displayed severe volatility after the implementation of the policy, suggesting that the policy failed to fulfill its duty as a "reservoir." How do we explain this outcome? More specifically, why did not the Chinese pork reserve regulation policy play its role in stabilizing the pork market price? This paper attempts to answer the question.

This paper is organized as follows. Section 2 describes the price volatilities in Chinese hog and pork market and then gives an introduction of the Chinese pork reserve regulation policy. Section 3 explains and analyzes the Reserve-Cobweb model in an agricultural commodity market. Section 4 describes the reformation of the competitive storage model developed by Muth (1961) in the context of price transmission. Section 5 empirically examines the impact of the Chinese pork reserve regulation policy on price volatility. Section 6 ends with conclusions and policy implications.

\section{The price volatilities of hog and pork markets and the pork reserve policy}

China is the world's largest nation in both hog production and pork consumption, accounting for about 50 percent of the hog production and pork consumption in the world. Pork is the most important meat product in the Chinese diet, accounting for more than 60 percent of China's total meat intake. Thus, the price of pork has a significant impact on Chinese food consumption. Since China's entry into the World Trade Organization, especially after 2006, the Chinese pork price has been volatile greatly. This has aroused widespread attention from both the government and the academics and consequently stimulated policy-makers to take measures to limit price volatility.

\subsection{Hog and pork price volatilities}

Chinese hog and pork prices had been stable before 2003. As shown in Figure 1, hog and pork prices keep basically at RMB 5 per kilogram and RMB 10 per kilogram, respectively. However, these prices have become increasingly volatile since May 2003. In order to measure the effect of reserve policy implemented on the pork market, we divide the fluctuations of pork prices into four distinct price cycles between 2003 and 2017.

The first cycle, between May 2003 and June 2006, lasted 38 months. During this period, the pork price increased by nearly 55 percent, from RMB 9.76 per kilogram in May 2003 to RMB 15.13 per kilogram in September 2004. Afterwards, the price dropped by about 30 percent by June 2006, which is RMB 10.58 per kilogram. The next cycle began in 




Source: China Animal Agriculture Association (www.caaa.cn/)

July 2006 and ended in June 2009, lasting 36 months. There was a notable upward trend of pork price from RMB 11.06 per kilogram in July 2006 to its peak at RMB 26.08 per kilogram in February 2008 - a sharp rise of 135.8 percent. The price decline then followed until June 2009, which reached RMB 15.46 per kilogram, a drop of 40.47 percent.

The third cycle continued from July 2009 to June 2015, lasting 72 months. This cycle can be further divided into five small cycles. The first one lasted from July 2009 to June 2010, with pork prices experiencing a mild fluctuation from RMB 16.27 per kilogram to RMB 19.31 per kilogram in January 2010 and then decreasing to RMB 16.04 per kilogram in June 2010. The second small cycle covered the period from July 2010 to June 2012 when pork prices rose from RMB 17.54 per kilogram to RMB 30.35 per kilogram in September 2011, increasing nearly 73 percent, and followed by a price fall to RMB 22.61 per kilogram in June 2012, a decline of 25.5 percent as compared with the September 2011 price. From August 2012 to June 2015, the price fluctuation in the pork market presented three small fluctuation cycles. The prices fluctuated from RMB 22.94 per kilogram in August 2012 to RMB 21.54 per kilogram in April 2015. It can be preliminarily concluded that, since the pork reserve regulation policy has been implemented, the pork market became more volatile for the frequency of pork price fluctuations increased while the wavelength decreased.

The final cycle took place from July 2015 to June 2017, lasting 24 months. During this period, the price in China rose from RMB 25.53 per kilogram in July 2015 to RMB 28.33 per kilogram in September 2015, decreased afterwards, to RMB 22.48 per kilogram in January 2016 , then rose again, to RMB 31.29 per kilogram in June 2016, and finally fell back to RMB 24.40 per kilogram in June 2017.

\subsection{Pork reserve regulation policy and its implementation}

The sharp decline of hog and pork prices from May 2008 has attracted the attention of the Chinese Government. In order to prevent excessive declines in pork price which could cause losses of farmers, the Chinese National Development and Reform Commission, the Ministry of Finance, the Ministry of Agriculture and the Ministry of Commerce in January 2009 announced "the regulation counter plan for preventing the excessive fall of hog prices (provisional)." According to this policy, the government decided to control hog market prices by operating a frozen pork buffer stock. In particular, the governments will buy pork 
CAER 11,2 for storage if the pork-grain-price ratio (PGR) is less than 5.5:1; whereas the governments will release stored frozen pork to the market if the ratio is more than 9:1. In May 2012, the government adjusted the PGR range to 6:1 and 8.5:1, respectively. This means the frozen pork reserve will be released if the PGR is more than 8.5:1, while the reserve will be increased if the PGR is less than 6:1.

Since the establishment of the pork price controlling mechanism that is based on the difference between the target and actual PGR, the government has used the buffer stock several times, attempting to stabilize hog prices (Figure 2). Nevertheless, both hog and pork prices have still exhibited significant volatility. As shown in Table I, the prices are still highly volatile when the governmental intervention measures are put into practice. While the standard deviation of the price in the third phase of volatility is not much less than in the previous phase, but it is still higher than in the first phase. Nevertheless, the buffer stocks increase the frequency of fluctuations, as there are five small cycles during the third phase of volatility. After June 2015, the government cut down its intervention in the pork market. For example, the government only released 0.1MT of pork from the reserve in September 2015. During this period, the pork market entered a relatively stable situation again. In order to examine the effect of the pork reserve policy, this paper thus only investigates the period between June 2009 and June 2015 when the government significantly had an intervention in the pork market.

\section{The Reserve-Cobweb model for price of agricultural commodities}

Ezekiel (1938) proposes one of the earliest formulations of agricultural price dynamics - the famous Cobweb theorem that describes a salient feature of agricultural markets (Gouel, 2012). The Cobweb model assumes that consumers' decisions are a function of product prices while farmers' producing decisions are a function of expected prices. Depending on the price elasticity of supply and demand, the Cobweb model can describe three different types of price behavior. When supply is more elastic than demand, prices and quantities diverge further and further away from equilibrium. Conversely, the price will converge to the initial condition gradually if demand is more elastic than supply. Moreover, the agricultural commodity price fluctuations will remain within a constant magnitude when the price elasticity of supply equals that of demand.

Engel's law dictates that the share of food expenditures declines when household income increases. As income elasticity declines, the food demand tends to be more price inelastic. According to the Cobweb model, the agricultural commodity market may exhibit divergent phenomenon because supply is more elastic than demand. Thus, price fluctuations tend to be relatively severe if the supply of food varies (Wright, 2001). Therefore, price intervention represents a policy tool used to smooth out price volatility in some countries in the world. During the Great Depression (1930s) and the Second World War, food was scarce around the world. Many economists such as Keynes $(1938,1942)$, Fisher (1920) and Hayek (1943) suggest that the government should use strategic reserves to stabilize food prices. Gustafson (1958) develops a storage model used to analyze random shocks induced by excessive supply. While this model receives wide acceptance for its logic of inter-temporal arbitrage, it fails to investigate the impact of random price rises and declines, suggesting that it is difficult to be validated using data and analysis techniques (Bobenrieth et al., 2013). Muth (1961) introduces a storage equation into the linear Cobweb model, regarding storage as an arbitrage tool. This model is named the competitive storage model (Table II).

In the storage arbitrage equation, Equation (5) in Table II, $\phi^{\prime}(X)_{t}$ is the variable of the marginal cost of storage, $X_{t}$ is the amount of storage, $\delta$ is the constant rate of depreciation and $r$ is the interest rate (i.e. the opportunity cost). Equation (5) indicates that stockpilers carry over positive stocks if the expected price is higher than the total cost that includes the marginal cost of storage, opportunity cost and depreciation. When the expected profit is negative, there are no stocks. Although many previous studies employed the competitive 


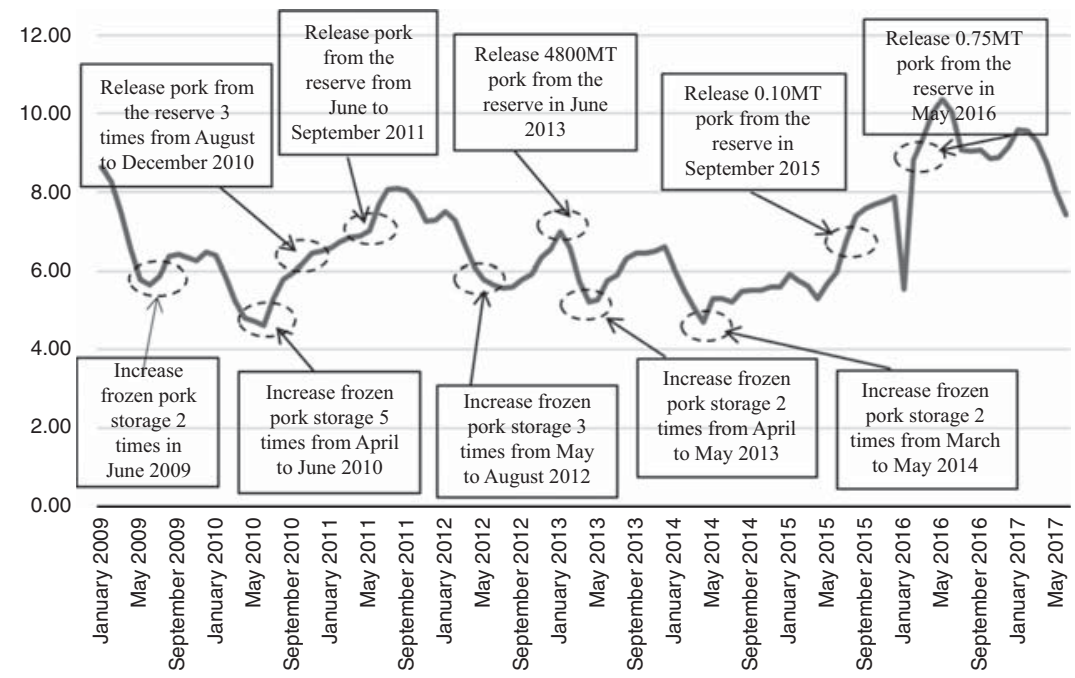

Note: PGR is the ratio of the pork price relative to the corn price

Source: PGR was from the website of the China Animal Agriculture Association. The data regarding releasing and increasing pork storage was from the website of the Ministry of Commerce of the People's Republic of China
Price transmission

359

Figure 2.

The trend of PGR and the frequency of pork reserve or release

\begin{tabular}{llcccc}
\hline $\begin{array}{l}\text { Fluctuation } \\
\text { cycle }\end{array}$ & Index & $\begin{array}{c}\text { Pig price } \\
\text { (RMB/kg) }\end{array}$ & $\begin{array}{c}\text { Growth rate of pig } \\
\text { price (\%) }\end{array}$ & $\begin{array}{c}\text { Pork price } \\
\text { (RMB/kg) }\end{array}$ & $\begin{array}{c}\text { Growth rate of pork } \\
\text { price (\%) }\end{array}$ \\
\hline May 2003-June & Mean & 7.75 & 0.41 & 12.63 & 0.23 \\
2006 & SD & 1.10 & 4.86 & 1.45 & 3.49 \\
& Maximum & 9.66 & 14.89 & 15.13 & 8.51 \\
& Minimum & 5.83 & -9.19 & 9.76 & -5.91 \\
July 2006-June & Mean & 12.16 & 1.51 & 19.28 & 1.25 \\
2009 & SD & 2.92 & 7.25 & 4.54 & 6.37 \\
& Maximum & 16.87 & 15.39 & 26.08 & 17.08 \\
July 2009-June & Minimum & 7.17 & -11.01 & 11.06 & -10.91 \\
2015 & Mean & 14.13 & 0.64 & 22.78 & 0.58 \\
& SD & 2.30 & 6.10 & 3.33 & 11.65 \\
& Maximum & 19.68 & 15.56 & 30.35 & -8.89 \\
July 2015-June & Minimum & 9.53 & -12.55 & 16.04 & 0.74 \\
2017 & Mean & 17.38 & 0.15 & 27.56 & 7.56 \\
& SD & 1.78 & 5.33 & 2.45 & 28.37 \\
& Maximum & 20.45 & 12.70 & 31.29 & -16.09
\end{tabular}

Source: China Animal Agriculture Association (www.caaa.cn/)

Table I.

The price fluctuations in Chinese hog and pork markets

$$
\begin{aligned}
& S t=a+b \hat{P}_{t}+\varepsilon_{t} \\
& D_{t}=c-d P_{t} \\
& \widehat{P}_{t}=E_{t-1}\left(P_{t}\right) \\
& D_{t}=S_{t}+(1-\delta) X_{t-1}-X_{t} \\
& P_{t} \geqslant \frac{1-\delta}{1-r} \hat{P}_{t+1}-\phi^{\prime}\left(X_{t}\right) \perp X_{t} \geqslant 0
\end{aligned}
$$

Production decision equation

Consumption behavior equation

Rational expectation equation

Market equilibrium equation

Storage arbitrage equation
(1)
Table II.

The competitive storage model 
CAER 11,2 storage model in their analysis (Lowry et al., 1987; Gardner, 1980; Chambers and Bailey, 1996; Ng and Ruge-Murcia, 2000; Osborne, 2004), empirical analysis with this model is inadequate because the marginal cost of storage is difficult to be estimated while reliable data for stored quantity is also rarely available. Therefore, this model represents only a theoretical approach and a simulative experiment.

In China, the reserve regulation policy is used to mitigate and manage price fluctuations instead of arbitrage. Thus, the cost of stockpiling is not an important consideration from the government's perspective. Hence, the reserve arbitrage equation in Muth's model is unsuitable in studying Chinese Government's reserve of agricultural products. Moreover, Muth's model does not consider the vertical transmission of agricultural commodity prices, and consequently the symmetrical or asymmetrical effect of price transmission in different parts of the agricultural supply chain is not reflected in the model. Peltzman (2000) finds that vertical price transmission is asymmetric. Therefore, a study on examining the effect of Chinese reserve regulation policy on pork price volatility should not only concern the zero marginal cost of the pork reserve, but also take into account of the asymmetric information effect of price transmission.

\section{The Storage-Cobweb model based on price transmission}

The modified Reserve-Cobweb model based on Muth's competitive storage model, the price transmission and Chinese reserve regulation policy is described in this section. The impact of Chinese pork reserve regulation on price volatility can be investigated, using this modified model in the context of price transmission in the pork supply chain.

\subsection{Assumptions}

The pork supply chain can be divided into several links, such as hog breeding, slaughtering, processing, and transportation, as well as pork wholesale and retail. In order to simplify the analysis, we only consider two segments of the pork supply chain: live hogs and pork retail, while other segments in the supply chain are ignored in this model.

The assumptions of the model are as follows:

(1) The quantity of pork in the consumer market equals the amount of hogs that farmers are willing to provide, while the supply of hogs depends on the hog price of the previous period.

(2) The demand for pork is a linear function of the pork price in the same period.

(3) The amount of pork sold from the government's pork reserve is a function of the difference between the market price and the expected price. Considering the lag in government decision-making behavior, the previous period market price is used as the expected price in the model.

(4) There is a transmission coefficient between hog and pork prices, thereby assuming that there exists a linear function between hog and pork prices.

(5) Because Chinese people prefer pork over other meat products, price fluctuations of chicken, beef and mutton have little effect on pork (Cao et al., 2012) and thus the substitution effect as well as the impact of changes in household income on pork price fluctuations can be ignored (Xiong, 2016)[1].

(6) In fact, the government makes decisions based on the difference between the target and actual PGR. Since corn prices are more stable than pork ones, we assume that the variable influencing the government's decision is only the difference between target and actual pork prices, instead of PGR, in order to make the model more concise. 
4.2 The Cobweb model based on price transmission and the government's reserve regulation policy

Based on the assumptions in Section 4.1, the model becomes:

$$
\begin{gathered}
S_{t}^{m}=S_{t}^{p}=a+b P_{t-1}^{p}, \\
D_{t}^{m}=c-d P_{t}^{m}, \\
T_{t}^{m}=e\left(P_{t-1}^{p}-P_{e}^{p}\right), \\
P_{t}^{p}=f+g P_{t}^{m},
\end{gathered}
$$

where $b>0, d>0, e>0$.

Equation (1) is the pork supply equation, where $S_{t}^{m}$ is the amount of pork supplied and $S_{t}^{p}$ stands for the amount of hogs supplied. If we ignore the weight of hog bones, hog offal, etc., the quantity of pork supplied substantially equals that of hogs, that is, $S_{t}^{m}=S_{t}^{p}$. The amount of hogs the farmers are willing to sell depends on the hog prices in the previous period, suggesting that the amount of hogs supplied in period $t$ is a function of the hog price in period $t-1$.

Equation (2) represents the demand equation for pork. $D_{t}^{m}$ is the quantity of pork demanded, which is a function of the pork price in the same period. Equation (3) is the behavior function of the government releasing the reserve. We assume this behavior function is continuous. When the government does not release the reserve, the amount of pork purchased or sold $T_{t}^{m}$ is zero. $P_{e}^{p}$ is the government's expected price or the hog target price. When the lagged hog price is higher than the target hog price, the government will release pork from the reserve to increase the pork supply and accordingly lower the pork prices. On the contrary, when the lagged pork price is lower than the target hog price, the government will purchase pork from the market for its reserve in order to reduce the pork supply and raise pork prices.

Equation (4) assumes that the hog price is a linear function of the pork price. $g$ is a transmission coefficient between these two prices. When $0<g<1$, hog prices change less than pork prices, which means that there is a dampening effect on the price volatility transferring from the pork retail market to the hog supply market. On the contrary, when $g>1$, any change in the pork price causes a larger change in hog prices. When $g=1$, the change in the hog price is equal to that of the pork price.

When the government intervenes in the market using pork reserve, the total quantity of pork supplied is the sum of the slaughtered hogs offered by farmers plus the frozen pork released from the pork reserves, which could be expressed as follows:

$$
S_{\text {total }}^{m}=S_{t}^{m}+T_{t}^{m}=a+b P_{t-1}^{p}+e\left(P_{t-1}^{p}-P_{e}^{p}\right) .
$$

If the hog market price in the previous period is lower than the government's target price, the government purchases hogs for reserve and then $T_{t}^{m}$ will have a negative value. At market equilibrium, pork supply equals pork demand. Therefore, Equation (5) could be rewritten as follows:

$$
D_{t}^{m}=S_{\text {total }}^{m}=S_{t}^{m}+T_{t}^{m}=a+b P_{t-1}^{p}+e\left(P_{t-1}^{p}-P_{e}^{p}\right) .
$$

The equation above indicates that the demand for pork equals the amount of hogs supplied by farmers and the pork bought or sold by the government. 
CAER 11,2

We assume that the expected hog price for the government, $P_{e}^{p}$, would be transformed to the expected pork price, thus the form of the function may still be employed for Equation (4). Subsequently, Equation (6) would be deduced as follows:

$$
D_{t}^{m}=a+b\left(f+g P_{t-1}^{m}\right)+e\left(f+g P_{t-1}^{m}-f-g P_{e}^{m}\right),
$$

where:

$$
c-d P_{t}^{m}=a+b f+(b+e) g P_{t-1}^{m}-e g P_{e}^{m} .
$$

Then:

$$
\begin{aligned}
& P_{t}^{m}=\frac{c-a-b f+e g P_{e}^{m}}{d}+\left[-\frac{(b+e) g}{d}\right] P_{t-1}^{m} \\
& =\frac{c-a-b f+e g P_{e}^{m}}{d}+\left[-\frac{(b+e) g}{d}\right]\left\{\frac{c-a-b f+e g P_{e}^{m}}{d}+\left[-\frac{(b+e) g}{d}\right] P_{t-2}^{m}\right\} \\
& \quad \cdots \cdots \\
& =\left[-\frac{(b+e) g}{d}\right]^{t} P_{0}^{m}+\left(\frac{c-a-b f+e g P_{e}^{m}}{d}\right) \times \frac{1-\left[-\frac{(b+e) g}{d}\right]}{1-\left[-\frac{(b+e) g}{d}\right]}
\end{aligned}
$$

where $P_{0}^{m}$ is the pork price in the first period. When the market is in equilibrium, $P_{t}^{m}=P_{t-1}^{m}=P_{b}^{m}$, where $P_{b}^{m}$ is the market equilibrium price.

From Equation (7) we can see that:

$$
e g P_{e}^{m}=a+b f-c+[(b+e) g+d] P_{t-1}^{m} .
$$

Substituting (9) into (8), the $P_{t}^{m}$ becomes as follows:

$$
P_{t}^{m}=\left[-\frac{(b+e) g}{d}\right]^{t} P_{0}^{m}+P_{b}^{m}\left\{1-\left[-\frac{(b+e) g}{d}\right]^{t}\right\}=\left[-\frac{(b+e) g}{d}\right]^{t}\left(P_{0}^{m}-P_{b}^{m}\right)+P_{b}^{m} .
$$

\subsection{The mechanism of the government's reserve regulation policy}

Equation (10) shows that if $(b+e) g>d$ and $P_{0}^{m} \neq P_{b}^{m}$, then $P_{t}^{m} \rightarrow \infty$ when $t \rightarrow \infty$. Otherwise, if $(b+e) g<d$, then $P_{t}^{m} \rightarrow P_{b}^{m}$ when $t \rightarrow \infty$. Thus, whether the pork market is in the divergent Cobweb case depends on four coefficients: the price elasticity of supply[2] $b$, the price elasticity of demand $d, e$ and $g$. Among them, $e$ is the elasticity of the price difference between pork's market price and government's target pork price. The greater the difference is, the larger the quantity of reserve pork is released by the government into the market. On the contrary, when the market price is lower than the target price, the government will purchase pork from the market for its stockpile, which means the released pork quantity from the government to the market is negative. The further the pork market price falls, the greater the quantity of pork the government will stockpile. Therefore, the elasticity coefficient $e$ in Equation (8) is positive. Moreover, the changes of $P_{t}^{p}$ and $P_{t}^{m}$ are positively correlated. When $P_{t}^{m}$ rises, $P_{t}^{p}$ will increase. Therefore, the coefficient $g$ is positive as well. Evidently, the reserve regulation policy in the pork market is not implemented continuously. Thus, when the government does not intervene in the pork market, $e$ equals zero, which indicates that the main coefficients to determine pork price volatility are $b, d$ and $g[3]$, where the values of $b$ and $d$ are fixed while the value of coefficient $g$ will influence price volatility directly.

When $g>1$, the hog price changes more than the pork price. When $g<1$, hog prices change less than pork prices do. Hence, the transmission coefficient $g$ has a significant 
impact on the volatility of hog and pork prices in our model. In addition, when $b, d$ and $g$ are fixed, the more sensitive the government responses to the market price are, the more severe the price fluctuations will be.

\section{The effect of China's pork reserve regulation policy on price volatility}

\subsection{Date source}

All the data used in this paper are from China's Government websites. More specifically, hog, corn and chicken price data are from the China Animal Agriculture Association Information website (www.caaa.cn/), pork prices and the quantity of live hogs from the Agricultural Information website of the Ministry of Agriculture of China, the average income[4] and the level of urbanization from China's National Bureau of Statistics, and the amounts of pork bought and sold by the buffer stock and the monthly amount of slaughtered hogs from the Ministry of Commerce's website. The Chinese Government carried out its reserve regulation policy starting in June 2009, while it has hardly ever intervened in the pork market after June 2015. Therefore, we test the effect of China's pork reserve regulation policy using the data between June 2009 and June 2015, covering 73 observations.

\subsection{Estimation of the elasticity of the demand for pork}

Data processing. The monthly data on slaughtered hogs are used as the amount of pork consumption $\left(D_{t}^{m}\right) . P_{t}^{m}$ stands for the pork market price, while the income of residents $\left(I N C_{t}\right)$ and chicken price $\left(P_{t}^{c}\right)$ are introduced as control variables in the models. Both the average income of residents and pork prices are deflated using the Consumer Price Index (CPI).

Unit root tests. In order to avoid "spurious regression" results, the unit root test of each variable is carried out first. Table III shows that the logarithmic variables of pork consumption $\left(D_{t}^{m}\right)$ and pork prices $\left(P_{t}^{m}\right)$ are stationary variables, while the logarithmic variables of the average income of residents $\left(I N C_{t}\right)$ and chicken price $\left(P_{t}^{c}\right)$ are integrated of order one.

Model estimation and analysis. Since $\operatorname{lnINC} C_{t}$ and $\ln P_{t}^{c}$ are non-stationary variables, so their first order differences would be regressed along with the stationary variables, $\ln D_{t}^{m}$ and $\ln P_{t}^{m}$. In order to compare the models including the control variables with those excluding controlling ones, we regress the three models using $\ln D_{t}^{m}, \ln P_{t}^{m}, d \cdot \ln I N C_{t}$ and $d . \ln P_{t}^{c}$ separately. As shown in Table IV, the parameters of pork price in all models are not significant, implying that the pork price has no impact on pork demand.

Elasticity prior to policy implementation. In order to compare the differences in demand-price elasticity before and after the implementation of the reserve regulation policy,

\begin{tabular}{lcccl}
\hline Variable & ADF test statistic & $(c, t, k)$ & $5 \%$ level & Conclusion \\
\hline $\ln D_{t}^{m}$ & -6.477 & $(\mathrm{c}, 0,1)$ & -2.913 & Stationary \\
$\ln P_{t}^{m}$ & -2.610 & $(\mathrm{c}, 0,1)$ & -2.913 & Stationary \\
$\ln I N C_{t}$ & -1.900 & $(\mathrm{c}, 0,1)$ & -2.913 & Non-stationary \\
$d \cdot \ln I C_{t}$ & -5.859 & $(\mathrm{c}, 0,1)$ & -2.914 & Stationary \\
$\ln P_{t}^{c}$ & -1.334 & $(\mathrm{c}, 0,1)$ & -2.913 & Non-stationary \\
$\operatorname{d} \cdot \ln P_{t}^{c}$ & -5.959 & $(\mathrm{c}, 0,1)$ & -2.914 & Stationary
\end{tabular}

Notes: $\ln D_{t}^{m}, \ln P_{t}^{m}, \ln I N C_{t}, \ln P_{t}^{c}$ denote the logarithmic series of amount of pork consumption, pork price, average income of residents and chicken price. $c$ is constant, $t$ represents trend and $k$ is lag length. The sample period covers from June 2009 to June 2015

Price
transmission

363
Table III.

The results of augmented Dickey-Fuller (ADF) tests 
CAER 11,2

364

we further measure the price elasticity of pork demand before the policy's implementation. The unit root and co-integration tests of variables are done prior to estimating the model. The logarithmic variables of pork consumption $\left(D_{t}^{m}\right)$, pork prices $\left(P_{t}^{m}\right)$, the average income of residents $\left(I N C_{t}\right)$ and chicken price $\left(P_{t}^{c}\right)$ are integrated of order one (see Table AI). Moreover, only one co-integration relationship exists in $\ln D_{t}^{m}$ and $\ln P_{t}^{m}$, as well as in $\ln D_{t}^{m}, \ln P_{t}^{m}$ and

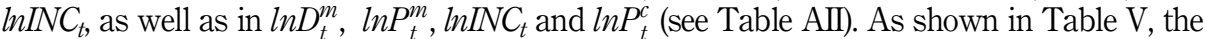
price elasticity of pork demand is relatively higher in absolute value prior to the policy implementation than it was during the policy's implementation period, suggesting that the null hypothesis that the government intervention lowers price does not rejected. Thus, it is concluded that the low price elasticity of pork demand is related to the implementation of the reserve policy.

\subsection{Estimation of the elasticity of pork supply}

Data processing. Since the amount of live hogs reflects the total number of hogs that farmers are willing to sell, the monthly quantity of live hogs as pork supply $\left(S_{t}^{p}\right)$ is used. Because farmers only consider the hog price, the hog prices $\left(P_{t}^{p}\right)$ are used to replace pork prices when estimating the price elasticity of pork supply. In addition to hog prices, production costs influencing the hog farmers' production behavior should also be taken into consideration. Thus, the corn price $\left(P_{t}^{c}\right)$ is introduced into the model as a control variable, which is used to represent the production cost. The data on corn prices are deflated using CPI.

Unit root and co-integration tests. The augmented Dickey-Fuller test is used to examine the stability of logarithmic variables including $S_{t}^{p}, P_{t}^{p}$ and $P_{t}^{c}$. The results from Table VI show that each variable is first-order integrated. Thus, the Johansen Test is employed to

Table IV.

Regression results of the pork demand equation during June 2009 to June 2015

\begin{tabular}{lccc}
\hline & Model $(1)$ & Model (2) & Model (3) \\
Variables & $\ln D_{t}^{m}$ & $\ln D_{t}^{m}$ & \multicolumn{1}{c}{$D_{t}^{m}$} \\
\hline $\ln P_{t}^{m}$ & $-0.00940(0.0812)$ & $-0.0460(0.0870)$ & $-0.0471(0.0885)$ \\
$d . \ln I N C_{t}$ & & $0.198(0.140)$ & $0.189(0.170)$ \\
$d . \ln P_{t}^{c}$ & & $7.680^{* * * *}(0.282)$ & $0.0653(0.550)$ \\
Constant & $7.561^{* * * *}(0.261)$ & 72 & $7.683^{* * * *}(0.286)$ \\
Observations & 73 & 0.026 & 72 \\
$R^{2}$ & 0.000 & & 0.026
\end{tabular}

Notes: This paper uses robust standard error to ensure the consistency of standard errors of the coefficients estimated

\section{Table V.}

Regression results of the pork demand equation prior to June 2009

\begin{tabular}{lccc}
\hline & Model $(1)$ & Model (2) & Model (3) \\
Variables & $\ln D_{t}^{m}$ & $\ln D_{t}^{m}$ & $\ln D_{t}^{m}$ \\
\hline $\ln P_{t}^{m}$ & $-1.003^{* * * *}(0.225)$ & $-0.878^{* * * *}(0.248)$ & $-0.744^{*}(0.376)$ \\
$\ln I N C_{t}$ & & $0.316(0.184)$ & $0.199(0.300)$ \\
$\ln P_{t}^{c}$ & & $7.900^{* * * *}(1.842)$ & $0.501(1.338)$ \\
Constant & $10.49^{* * *}(0.700)$ & 18 & $6.893^{*}(3.617)$ \\
Observations & 18 & 0.525 & 18 \\
$R^{2}$ & 0.420 & 0.535
\end{tabular}

Notes: This paper uses robust standard error to ensure the consistency of standard errors of the coefficients estimated 
examine the co-integration between $\ln S_{t}^{\phi}, \ln P_{t}^{p}$ and $\ln P_{t}^{c}$. The results in Table VII show that only one co-integration relationship exists in $\ln S_{t}^{p}$ and $\ln P_{t}^{c}$, as well as in, $\ln P_{t}^{p}$ and $\ln P_{t}^{c}$.

Model estimation and analysis. Table VIII presents the regression models with $\ln P_{t-1}^{p}$ and $\ln P_{t}^{c}$ as an independent variable, respectively. The results in the table show that the parameters estimated for hog prices are statistically significant at conventional levels. Moreover, the parameter estimated for corn price in model (2) is negative and statistically significant at conventional levels. Combining the results of the elasticity of demand and supply shown in Tables IV and VIII, it is concluded that the hog price is a classic divergent Cobweb case. In other words, the volatilities of hog and pork prices present the feature the divergent Cobweb model depicts in the setting of the reserve regulation policy.

The transmission effect between hog price and pork price. The transmission coefficient between hog and pork prices has an important impact on market price (whether it is unidirectional or bidirectional). Due to a lack of monthly data on stockpiling or releasing pork, we are unable to estimate the government responses to market price. Hence, we focus on the test transmission coefficient between hog and pork prices.

\begin{tabular}{lcccl}
\hline Variable & ADF test statistic & $(c, t, k)$ & $5 \%$ level & Conclusion \\
\hline $\ln S_{t}^{p}$ & -1.340 & $(\mathrm{c}, 0,1)$ & -2.913 & Non-Stationary \\
$d \cdot \ln S_{t}^{p}$ & -4.768 & $(\mathrm{c}, 0,1)$ & -2.914 & Stationary \\
$\ln P_{t}^{p}$ & -2.346 & $(\mathrm{c}, 0,1)$ & -2.913 & Non-stationary \\
$d \cdot \ln P_{t}^{p}$ & -4.630 & $(\mathrm{c}, 0,1)$ & -2.914 & Stationary \\
$\ln P_{t}^{c}$ & -1.175 & $(\mathrm{c}, 0,1)$ & -2.913 & Non-stationary \\
$d \cdot \ln P_{t}^{c}$ & -4.439 & $(\mathrm{c}, 0,1)$ & -2.914 & Stationary
\end{tabular}

Notes: $\ln S_{t}^{p}, \ln P_{t}^{p}$ and $\ln P_{t}^{c}$ denote the logarithmic series of the amount of monthly pig breeding stock, pig price and corn price, respectively. $c$ is constant, $t$ represents trend and $k$ is lag length. The sample period covers from June 2009 to June 2015
Price
transmission

365

\begin{tabular}{lccrcl}
\hline Model & $H_{0}$ & $H_{1}$ & \multicolumn{1}{c}{ LRT } & 5\% Level & Conclusion \\
\hline $\ln S_{t}^{p}$ and $\ln P_{t}^{p}$ & $R=0$ & $R=1$ & 15.5084 & 15.41 & Reject null hypothesis \\
$\ln S_{t}^{p}, \ln P_{t}^{p}$ and $\ln P_{t}^{c}$ & $R \leqslant 1$ & $R=2$ & 0.9695 & 3.76 & Accept null hypothesis \\
& $R=0$ & $R=1$ & 51.6555 & 29.68 & Reject null hypothesis \\
& $R \leqslant 1$ & $R=2$ & 13.2520 & 15.41 & Accept null hypothesis \\
& $R \leqslant 2$ & $R=3$ & 5.3497 & 3.76 & Accept null hypothesis
\end{tabular}

Notes: $R$ represents the number of co-integration vector

Table VII. Johansen co-integration tests for $\ln S_{t}^{p}, \ln P_{t}^{p}$ and $\ln P_{t}^{c}$

\begin{tabular}{lcc}
\hline Variables & Model $(1)$ & \multicolumn{1}{c}{ Model (2) } \\
$\ln S_{t}^{p}$ \\
\hline $\ln P_{t-1}^{p}$ & $0.100^{* * * *}(0.0243)$ & $0.146^{* * * *}(0.0219)$ \\
$\ln P_{t}^{c}$ & & $-0.183^{* * * *}(0.0415)$ \\
Constant & $10.43^{* * *}(0.0683)$ & $10.48^{* * * *}(0.0566)$ \\
Observations & 72 & 72 \\
$R^{2}$ & 0.087 & 0.279
\end{tabular}

Notes: This paper uses robust standard error to ensure the consistency of standard errors of the coefficients estimated; $\ln P_{t-1}^{p}$ denote one lag for pig price. Robust standard errors are in parentheses

Table VIII.

Regression results of the pork supply equation 
CAER 11,2

366

Figure 3 shows that the volatility of hog prices is more dramatic than that of pork prices, suggesting that the information about the price transmission between hog and pork is asymmetric. Previous studies have found that Chinese pork price exhibits such an asymmetric transmission effect. Xin and Tan (2000) show that there is an amplifying effect of changes in pork demand on pork prices, whereas there is a mitigating effect of pork supply changes on pork prices. Hu and Li (2010) indicate that the Chinese pork supply chain exhibits an observably asymmetric price transmission feature and that the price transmission speed is higher and more important if the price rises than if it falls. Feng (2013) finds that pork price volatility caused by a positive shock is more aggressive than the fluctuations resulting from a negative shock. Yu and Zheng (2013) show that the change of hog price is not totally transmitted to the downstream products. While these previous studies have found that there is an asymmetric transmission effect in the Chinese pork prices, they fail to draw a quantifiable conclusion about hog and pork price elasticities. Thus, We in this section employs time series data and panel data, respectively, to estimate various transmission effects as hog and pork prices rise or fall (Figure 4).

An analysis using time series data. In order to test the transmission effect between two price variables, the deflation on price variables is not necessary, and the data on pork and hog prices that are not deflated are used in the model directly. According to the result of the unit root test (see Table IX), the first-order difference of logarithmic pork prices and the hog prices are stationary series. We perform a Granger causality test on the first-order difference values. As shown in Table $\mathrm{X}$, the growth rate of hog and pork prices exhibit mutual causality. Results of the tests on the co-integration between $\ln P_{t}^{p}$ and $\ln P_{t}^{m}$ show that only one co-integration relationship exists in $\ln P_{t}^{p}$ and $\ln P_{t}^{m}$ (Table XI). Therefore, the ordinary least squares can be used in the regressions while the Newey-West method is used to correct possibly biased standard errors of parameter estimates. As shown in Table XII, the hog price will increase by 0.95 percent if the pork price rises by 1 percent, whereas a change of 1 percent in hog price will trigger a 0.83 percent change in the pork price. While the volatility

Figure 3.

The growth rates of pig price and pork price from June 2009 to June 2015 (unit: percent)
Figure 4. Elasticity of effect between hog and pork prices

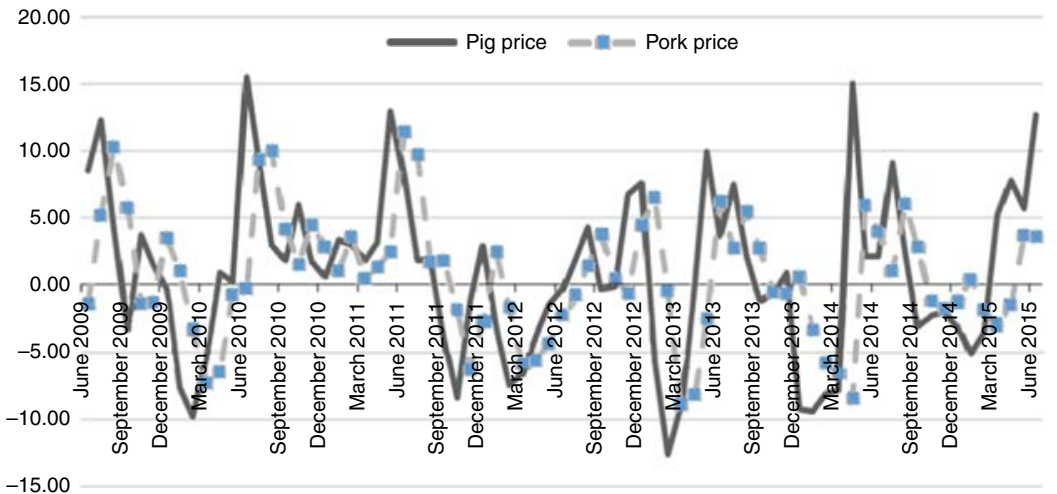

Source: China Animal Agriculture Association (www.caaa.cn/)

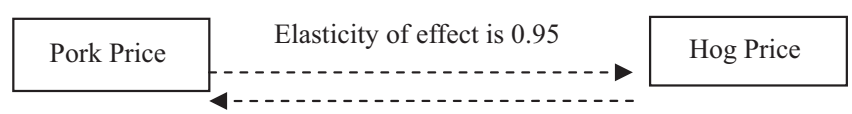

Elasticity of effect is 0.83 
caused by an upstream link has a weaker effect on price transmission to downstream links, price transmission effects in general have little difference between pork-to-hog and hog-topork price volatilities.

An analysis using panel data. The regression results in Table XIII have not captured the price transmission effect when the price is rising or decreasing. In order to examine the transference effect between pork and hog prices when prices rise or fall, we divide the sample period from June 2009 to June 2015 into two parts: the periods of rising and of falling prices, respectively. We thus utilizes the panel data model to investigate the different transmission effects from pork to hog price and from hog to pork price, respectively, under the price-rising and price-falling scenarios. Unlike the single time-series data regression that might provide spurious results, the panel data regression estimation gives a consistent estimate of the parameter. Hence, a short-period panel data model does not rely on stationary tests.

\begin{tabular}{lcccl}
\hline Variable & ADF test statistic & $(c, t, k)$ & $5 \%$ level & Conclusion \\
\hline $\ln P_{t}^{p}$ & -2.552 & $(c, 0,1)$ & -2.913 & Non-stationary \\
$d \cdot \ln P_{t}^{p}$ & -4.936 & $(c, 0,1)$ & -2.914 & Stationary \\
$\ln P_{t}^{m}$ & -2.859 & $(c, 0,1)$ & -2.913 & Non-stationary \\
$d \cdot \ln P_{t}^{m}$ & -5.825 & $(c, 0,1)$ & -2.914 & Stationary
\end{tabular}

Notes: $\ln P_{t}^{p}$ and $\ln P_{t}^{m}$ denote the logarithmic series of pig price and pork price, respectively. $c$ is constant, $t$ represents trend and $k$ is lag length. The sample period covers from June 2009 to June 2015

\begin{tabular}{lll}
\hline Explanatory variable dependent variable & $d \cdot \ln P_{t}^{p}$ & $d \cdot \ln P_{t}^{m}$ \\
\hline$d \cdot \ln P_{t}^{p}$ & & $638.37^{* * *}(0.000)$ \\
$d \cdot \ln P_{t}^{m}$ & $4.16^{* *}(0.038)$ &
\end{tabular}

Notes: According to the report of AIC, we choose one lags in the VAR model. $H_{0}$ indicates that there is no causality between the variables. “***”Denotes statistical level at 1 percent

Table IX. ADF tests for $\ln P_{t}^{p}$ and $\ln P_{t}^{m}$

\begin{tabular}{lllccl}
\hline Model & $H_{0}$ & $H_{1}$ & LRT & $5 \%$ Level & Conclusion \\
\hline $\ln P_{t}^{p}$ and $\ln P_{t}^{m}$ & $R=0$ & $R=1$ & 19.1440 & 15.41 & Reject null hypothesis \\
& $R \leqslant 1$ & $R=2$ & 3.3012 & 3.76 & Accept null hypothesis
\end{tabular}

Notes: $R$ represents the number of co-integration vector

Table XI.

Johansen co-integration test for $\ln P_{t}^{p}$ and $\ln P_{t}^{m}$

\begin{tabular}{|c|c|c|c|c|}
\hline Variables & $\begin{array}{c}\text { Model(1) } \\
\ln P_{t}^{p}\end{array}$ & Variables & $\begin{array}{c}\text { Model(2) } \\
\ln P_{t}^{m}\end{array}$ & \\
\hline $\begin{array}{l}\ln P_{t}^{m} \\
\text { Constant } \\
\text { Observations } \\
R^{2} \\
\text { Notes: Values }\end{array}$ & $\begin{array}{c}0.95^{* * * *}(12.48) \\
-0.32(-1.36) \\
73 \\
0.98 \\
\text { are } t \text {-values }\end{array}$ & $\begin{array}{l}\ln P_{t}^{p} \\
\text { Constant } \\
\text { Observations } \\
R^{2}\end{array}$ & $\begin{array}{c}0.83^{* * * *}(11.49) \\
0.93^{* * * *}(4.80) \\
73 \\
0.98\end{array}$ & $\begin{array}{l}\text { Table XII. } \\
\text { The regression results } \\
\text { for the transmission } \\
\text { effect using time } \\
\text { series data }\end{array}$ \\
\hline
\end{tabular}


CAER 11,2

368

Table XIII.

The regression results for the transmission effect in the price-rising period using panel data
While the price data in the price-rising period for both hog and pork prices are built using the unbalanced panel data, a fixed-effect model is performed accordingly (see Table XIII). Similarly, the price data in the price-falling period are established using the unbalanced panel data while a fixed-effect model is conducted (see Table XIV). As shown in Tables XIII and XIV, the price transferring effect is obtained from the consumer markets to the hog breeding chain, while it is got from the hog breeding chain to the consumer markets.

There is a visible difference in the transferring effect between from pork price to hog price and from hog price to pork price (Figures 5 and 6). As shown in Equation (9), there exists an obvious amplification effect in price transfer from pork to hog price, suggesting that there is a classical "Bullwhip Effect" on price volatility in the transmission process from the consumer market to the breeding chain. Moreover, the amplification effect of pricefalling is slightly stronger than that of price-rising if the volatility of hog prices is generated in the consumer market (Figure 5). This outcome evinces a positive asymmetric price transmission in the price transmission process (Meyer and von Cramon-Taubadel, 2004). That is, price changes for squeezing profits is more rapid than price changes for increasing profits. The results above indicate that the farmers will encounter greater market risk if the pork price-falling is caused by a decrease in demand, however, if the volatility of pork price

\begin{tabular}{lclc}
\hline Variables & $\begin{array}{c}\text { Model(1) } \\
\ln P_{t}^{p}\end{array}$ & Variables & $\begin{array}{c}\text { Model(2) } \\
\ln P_{t}^{m}\end{array}$ \\
\hline $\ln P_{t}^{m}$ & $1.06^{* * * *}(25.56)$ & $\ln P_{t}^{p}$ & $0.75^{* * * *}(12.08)$ \\
Constant & $-0.62^{* * * *}(-4.88)$ & Constant & $1.08^{* * * *}(6.58)$ \\
Observations & 41 & Observations & 41 \\
$R^{2}$ & 0.998 & $R^{2}$ & 0.98
\end{tabular}

Note: Values in parentheses are $t$-values
Table XIV.

The regression results for the transmission effect in the pricefalling period using panel data

\begin{tabular}{lclc}
\hline Variables & $\begin{array}{c}\text { Model(1) } \\
\ln P_{t}^{p}\end{array}$ & Variables & $\begin{array}{c}\text { Model(2) } \\
\ln P_{t}^{m}\end{array}$ \\
\hline $\ln P_{t}^{m}$ & $1.08^{* * *}(5.00)$ & $\ln P_{t}^{p}$ & $0.49 * *(3.12)$ \\
Constant & $-0.81(-1.18)$ & Constant & $1.87^{* * *}(4.55)$ \\
Observations & 31 & Observations & 31 \\
$R^{2}$ & 0.94 & $R^{2}$ & 0.94
\end{tabular}

Notes: Values in parentheses are $t$-values

\section{Figure 5.}

Elasticity effect from consumer market to hog breeding chain

Figure 6.

Elasticity effect from hog breeding chain to consumer market

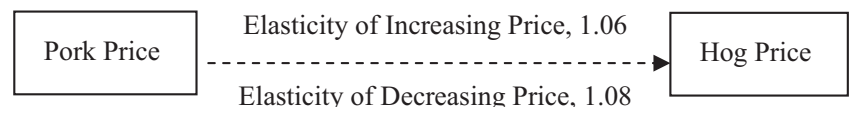

Elasticity of Decreasing Price, 1.08

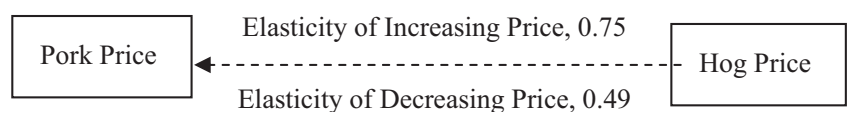


is induced by its link to hog breeding (Figure 6), there exists a weakening effect on price transmission and the weakening effect of price falling is larger than that of price-rising.

According to Equation (10), the supply elasticity $b$ is 0.146 , the demand elasticity $d-0.046$, and the price transmission coefficient $g 1.06$ or 1.08 . Thus, $e$, representing the government's response to market prices, will be larger than one either when $g=1.06$ or when $g=1.08[5]$. Therefore, $P_{t}^{m} \rightarrow \infty$ when $t \rightarrow \infty$. It can be concluded that China's pork market is a typical case the divergent Cobweb model describes. In addition, if supply and demand elasticity and the price transmission coefficient remain unchanged, the more sensitive the government's response to market prices is, the more volatile the market prices will be.

\section{Conclusions and policy implications}

This paper examines the impact of the pork reserve policy on the volatility of hog and pork prices in China, using a modified Reserve-Cobweb model and the Chinese price data on pork and hog prices from June 2009 to June 2015. Results of this paper show that the government intervention with a reserve regulation policy tool is expected to increase the price volatility in the pork market if the prices of agricultural products exhibit a divergent Cobweb pattern and positive asymmetric price information transmission mode.

Since Chinese hog price fluctuations present a divergent Cobweb pattern under the implementation of a reserve regulation policy, the goal of the reserve regulation policy has not been achieved. Moreover, there exists one asymmetric effect on the price transmission between hogs and pork. More specifically, there is a magnification effect on the price transmission from the pork to hog price, which enlarges price volatility as well as induces hypercorrection by the reserve regulation policy. As the Chinese Government intervenes in the consumption market for pork directly instead of the hog supply chain, the hog price volatility becomes more serious when the government has an intervention in the market price with a pork reserve.

In summing up, the asymmetric transmission of price in different links of the pork supply chain would make it difficult for the reserve regulation policy to function effectively. What is worse is that the reserve regulation policy might result in a hypercorrection and finally intensify market volatility. Therefore, the reserve regulation policy not only cannot stabilize pork prices, but also instead aggravate market volatility. Not surprisingly, the Chinese Government has cut down its intervention in the pork market after June 2015 and consequently, the pork prices have presented more stable after June 2015 than during the period of the government's intervention.

\section{Notes}

1. This assumption is just for simplified theoretical analysis. These two types of variable are included in the demand function in the empirical models.

2. Since logarithmic variables are employed in the model, the coefficients of variables are the elasticities.

3. If the government does not intervene in the pork market, Equation (3) does not exist, that is, $P_{t}^{m}=\left(-\frac{b g}{d}\right)^{t}\left(P_{0}^{m}-P_{e}^{m}\right)+P_{e}^{m}$

4. Since there are no data on resident's incomes, we calculate the average income of residents as the average of the per capita cash income of rural households and the per capita disposable income of urban households, weighted by the share of rural and urban population.

5. $((b+e) g / d)=(b \times g+e+g / d)=(3.68+23.04 e)>1$ when $g=1.06$, and $((b+e) g / d)=(3.43+23.48 e)$ $>1$ when $g=1.08$. Even if using $g=0.75$ or $g=0.49,((b+e) g / d)$ is still greater than 1 . 
CAER 11,2

\section{References}

Anokye, M. and Oduro, F.T. (2013), "Cobweb Model with buffer stock for the stabilization of tomato prices in Ghana", Journal of Management and Sustainability, Vol. 3 No. 1, pp. 155-165.

Bobenrieth, E.S. and Wright, B.D. (2009), "The food price crisis of 2007/2008: evidence and implications" Joint Meeting of the Intergovernmental Group on Oilseeds, Oils and Fats (30th Session), the Intergovernmental Group on Grains (32nd Session) and the Intergovernmental Group on Rice (43rd Session), Santiago.

Bobenrieth, E.S., Bobenrieth, J.R. and Wright, B.D. (2013), Bubble Troubles? Rational Storage, Mean Reversion and Runs in Commodity Prices [R], National Bureau of Economic Research.

Cao, J.M., Tian, L. and Zhang, Y.J. (2012), "Study on the consumption of beef in China and its response to pork price", Chinese Journal of Animal Science, Vol. 48 No. 12, pp. $12-15$ (in Chinese).

Chambers, M.J. and Bailey, R.E. (1996), "A theory of commodity price fluctuations”, The Journal of Political Economy, Vol. 104 No. 5, pp. 924-957.

Cheng, G., Hu, B. and Xu, X. (2008), "An analysis of the impact of the new round of rise in the prices of agricultural produce”, Management World, Vol. 21 No. 1, pp. 57-64 (in Chinese).

Ezekiel, M. (1938), "The cobweb theorem”, The Quarterly Journal of Economics, Vol. 52 No. 2, pp. 255-280.

Feng, M. (2013), "The asymmetric volatility of pork price and its impact on CPI", Statistical Research, Vol. 30 No. 8, pp. $63-68$ (in Chinese).

Fisher, I. (1920), Stabilizing the Dollar[M], The Macmillan Company, New York, NY.

Gardner, B.L. (1980), Optimal Stockpiling of Grain [M], Lexington Books.

Gouel, C. (2012), "Agricultural price instability: a survey of competing explanations and remedies", Journal of Economic Surveys, Vol. 26 No. 1, pp. 129-156.

Gustafson, R.L. (1958), Carryover Levels for Grains: A Method for Determining Amounts that are Optimal Under Specified Conditions [M], US Department of Agriculture.

Hayek, E.A. (1943), “A commodity reserve currency (in post-war problems)”, Economic Journal, Vol. 53 No. 2, pp. 176-184.

$\mathrm{Hu}, \mathrm{H}$. and Li, C.G. (2010), “Agricultural products' horizontal price transmission and vertical market jointing”, Issues in Agricultural Economy, Vol. 1, pp. 10-17 (in Chinese).

IMF and UNCTAD (2011), "Price volatility in food and agricultural markets: policy responses" Food and Agricultural Organization, pp. 1999-2008.

Keynes, J.M. (1938), "The policy of government storage of foodstuffs and raw materials", Economic Journal, Vol. 48 No. 191, pp. 449-460.

Keynes, J.M. (1942), "The international regulation of primary products", Collected Writings of JM Keynes, Vol. 27.

Lowry, M., Glauber, J., Miranda, M. and Helmberger, P. (1987), "Pricing and storage of field crops: a quarterly model applied to soybeans", American Journal of Agricultural Economics, Vol. 69 No. 4, pp. 740-749.

Meyer, J. and von Cramon-Taubadel, S. (2004), “Asymmetric price transmission: a survey”, Journal of Agricultural Economics, Vol. 55 No. 3, pp. 581-611.

Muth, J.E. (1961), "Rational expectations and the theory of price movements", Econometrica, Vol. 29 No. 3, pp. 315-335.

$\mathrm{Ng}$, S. and Ruge-Murcia, F.J. (2000), "Explaining the persistence of commodity prices", Computational Economics, Vol. 16 Nos 1-2, pp. 149-171.

Osborne, T. (2004), "Market news in commodity price theory: application to the Ethiopian grain market", The Review of Economic Studies, Vol. 71 No. 1, pp. 133-164.

Peltzman, S. (2000), "Prices rise faster than they fall", Journal of Political Economy, Vol. 108 No. 3, pp. $466-502$. 
Piot-Lepetit, I. and M'Barek, R. (2011), Methods to Analyse Agricultural Commodity Price Volatility[M], Springer, New York, NY, pp. 1-11.

Vercammen, J. (2012), Agricultural Marketing: Structural Models for Price Analysis[M], Routledge, pp. 35-59.

Wright, B. (2001), "Storage and price stabilization", Handbook of Agricultural Economics, Vol. 1, Part B, pp. 817-861.

Xin, X. and Tan, X.Y. (2000), "On agricultural commodity price amplifying effect”, China Rural Survey, Vol. 1, pp. $52-57$ (in Chinese).

Xiong, J. (2016), "Study on the characteristics and influence factors of food consumption of chinese residents[M]", dissertation, Chinese Academy of Agricultural Sciences.

Yu, A.Z. and Zheng, S.H. (2013), "Research on the asymmetric price transfer in China's pork industry China”, Journal of Agrotechnical Economics, Vol. 9, pp. 35-41 (in Chinese).

\section{Further reading}

Baltagi, B. (2008), Econometric Analysis of Panel Data[M], John Wiley \& Sons.

Chavas, J.P., Hummels, D. and Wright, B.D. (2014), Introduction to "The Economics of Food Price Volatility"[M], University of Chicago Press, pp. 1-11.

Larson, D.F., Lampietti, J., Gouel, C., Cafiero, C. and Roberts, J. (2013), "Food security and storage in the Middle East and North Africa”, The World Bank Economic Review, Vol. 28 No. 1, pp. 48-73.

Williams, J.C. and Wright, B.D. (2005), Storage and Commodity Markets[M], Cambridge University Press. 
CAER

11,2

372

Table AI.

The results of augmented Dickey-Fuller $(\mathrm{ADF})$ tests

\section{Appendix}

\begin{tabular}{lcccl}
\hline Variable & ADF test statistic & $(c, t, k)$ & $10 \%$ level & Conclusion \\
\hline $\ln D_{t}^{m}$ & -1.468 & $(\mathrm{c}, 0,1)$ & -2.630 & Non-Stationary \\
$d \cdot \ln D_{t}^{m}$ & -4.001 & $(\mathrm{c}, 0,1)$ & -2.630 & Stationary \\
$\ln P_{t}^{m}$ & -1.483 & $(\mathrm{c}, 0,1)$ & -2.630 & Non-Stationary \\
$d \cdot \ln P_{t}^{m}$ & -3.152 & $(\mathrm{c}, 0,1)$ & -2.630 & Stationary \\
$\ln I N C_{t}$ & -1.386 & $(\mathrm{c}, 0,1)$ & -2.630 & Non-stationary \\
$d \cdot \ln I N C_{t}$ & -3.303 & $(\mathrm{c}, 0,1)$ & -2.630 & Stationary \\
$\ln P_{t}^{c}$ & 0.079 & $(\mathrm{c}, 0,1)$ & -2.630 & Non-stationary \\
$d \cdot \ln P_{t}^{c}$ & -2.802 & $(\mathrm{c}, 0,1)$ & -2.630 & Stationary
\end{tabular}

Notes: $\ln D_{t}^{m}, \ln P_{t}^{m}, \ln I N C_{t}$ and $\ln P_{t}^{c}$ denote the logarithmic series of amount of pork consumption, pork price, average income of residents and chicken price, respectively. $c$ is constant, $t$ represents trend and $k$ is lag length. The sample period covers from January 2008 to June 2009
Table AII

The results of Johansen co-integration tests

\begin{tabular}{lcccrl}
\hline Model & $H_{0}$ & $H_{1}$ & Likelihood Ratio Test (LRT) & 5\% Level & Conclusion \\
\hline $\ln D_{t}^{m}$ and $\ln P_{t}^{m}$ & $R=0$ & $R=1$ & 36.3822 & 15.41 & Reject null hypothesis \\
& $R \leqslant 1$ & $R=2$ & 0.5634 & 3.76 & Accept null hypothesis \\
$\ln D_{t}^{m}$ and $\ln P_{t}^{m}, \ln I N C_{t}$ & $R=0$ & $R=1$ & 64.9046 & 29.68 & Reject null hypothesis \\
& $R \leqslant 1$ & $R=2$ & 11.9356 & 15.41 & Accept null hypothesis \\
& $R \leqslant 2$ & $R=3$ & 0.4079 & 3.76 & Accept null hypothesis \\
$\ln D_{t}^{m}$ and $\ln P_{t}^{m}, \ln I N C_{t}, \ln P_{t}^{c}$ & $R=0$ & $R=1$ & 47.9734 & 47.21 & Reject null hypothesis \\
& $R \leqslant 1$ & $R=2$ & 17.3725 & 29.68 & Accept null hypothesis \\
& $R \leqslant 2$ & $R=3$ & 3.5156 & 15.41 & Accept null hypothesis
\end{tabular}

Note: $R$ represents the number of co-integration vector

Corresponding author

Yanwen Tan can be contacted at: tanyw@scau.edu.cn

For instructions on how to order reprints of this article, please visit our website: 